\title{
ISOLASI KOI HERPESVIRUS (KHV) DARI BEBERAPA ORGAN TARGET DENGAN MENGGUNAKAN KULTUR SEL KT- 2
}

\author{
Tuti Sumiati*) dan Agus Sunarto*) \\ *) Balai Penelitian dan Pengembangan Budidaya Air Tawar \\ Jl. Raya Sempur No. 1, Bogor 16154 \\ E-mail: tuti.sumiati@yahoo.co.id \\ **) Pusat Penelitian dan Pengembangan Perikanan Budidaya \\ JI. Ragunan 20, Pasar Minggu, Jakarta Selatan 12540
}

(Naskah diterima: 5 Mei 2011; Disetujui publikasi: 1 Maret 2012)

\begin{abstract}
ABSTRAK
Kasus kematian massal pada ikan mas dan koi (Cyprinus carpio) yang disebabkan oleh koi herpesvirus (KHV) terjadi sejak tahun 2002 dan masih berlangsung hingga sekarang. Pemilihan sampel yang tepat sangat penting untuk mendeteksi dan mengidentifikasi penyakit KHV tersebut. Tujuan dari penelitian ini adalah untuk mengetahui jaringan yang menjadi target infeksi KHV dengan cara isolasi virus menggunakan kultur sel KT- 2. Kultur sel diinokulasi dengan ekstrak jaringan organ target (otak, mata, insang, ginjal, limfa, hati, jantung, dan usus, serta gabungan insang, ginjal, dan limfa) dan diinkubasi pada suhu $25^{\circ} \mathrm{C}$ selama 14 hari. Kerusakan sel terjadi pada kultur sel yang diinokulasi dengan ekstrak dari jaringan insang, ginjal dan gabungan organ insang, ginjal, dan limfa. Uji PCR dari media kultur dan sel yang mengalami CPE menunjukkan bahwa CPE disebabkan oleh KHV.
\end{abstract}

KATA KUNCI: KHV, organ target, kultur sel, isolasi virus, CPE, PCR

ABSTRACT: Isolation of koi herpesvirus (KHV) from several target tissues using KT- 2 fish cell culture. By: Tuti Sumiati and Agus Sunarto

Mass mortality of koi and common carp (Cyprinus carpio) caused by koi herpesvirus (KHV) occured since 2002 is continuing at moment. Appropriate sample is crucial for the detection and identification of the KHV disease. The aim of this research is to investigate the major sites of KHV infection by isolating the virus from several target tissues using KT-2 fish cell culture. The cell cultures were inoculated with tissue extract from target tissues (brain, eye, gills, kidney, spleen, liver, heart, intestine, and pooled of gill, kidney and spleen) and incubated at $25^{\circ} \mathrm{C}$ for 14 days. Cythophatic effect (CPE) was observed in cell cultures inoculated with gill, kidney and pooled of gill, kidney, and spleen. Polymerase Chain Reaction (PCR) assay of tissue cultures supernatant and cells showing CPE confirmed that the CPE was caused by KHV.

KEYWORDS: koi herpesvirus, target tissue, KT- 2 cell culture, CPE, PCR 


\section{PENDAHULUAN}

Perikanan budidaya menjadi harapan bagi peningkatan produksi perikanan dalam memenuhi permintaan pasar baik domestik maupun internasional. Dampak lanjut dengan adanya intensifikasi budidaya perikanan adalah terjadinya berbagai kasus serangan penyakit. Kasus serangan penyakit tersebut telah mengakibatkan kerugian yang signifikan baik dari aspek ekonomi maupun sosial, dan berakibat kurang menguntungkan bagi industri perikanan budidaya di Indonesia. Salah satu kasus serangan penyakit pada ikan air tawar yang menyebabkan kerugian ekonomi dan sosial sangat besar adalah kematian massal pada ikan mas dan koi akibat infeksi koi herpesvirus, KHV (Sunarto et al., 2005a).

Penyakit KHV pertama kali dilaporkan terjadi di Israel dan Amerika Serikat pada tahun 1998 (Hedrick et al., 2000), selanjutnya menyebar ke berbagai negara (Hoffman et al., 2002; Way et al., 2002; Sano et al., 2004; Tu et al., 2004). Di Indonesia, kasus kematian massal pada ikan mas dan koi pertama kali dilaporkan terjadi pada tahun 2002 di daerah Blitar (Sunarto et al., 2005a). Wabah ini terus berlanjut dan menyebar hampir ke seluruh wilayah di Indonesia, dari Sumatera sampai ke Papua (Sunarto \& Cameron, 2005) dan masih terus berlanjut hingga saat ini.

Koi herpesvirus merupakan penyakit paling mematikan pada budidaya ikan air tawar di Indonesia. Penyakit ini dapat menyebabkan kematian ikan mas dan koi antara 80\%-95\% dalam waktu 2 minggu (Perelberg et al., 2003). Gejala klinis dari ikan yang terinfeksi KHV ditandai dengan produksi lendir yang berlebihan, adanya kerusakan insang dan terjadi pendarahan pada sirip, kulit serta internal organ. KHV pertama kali berhasil diisolasi dari organ insang serta gabungan ginjal dan limfa (Hedrick et al., 2000). Selanjutnya Neukirch \& Kunz (2001), Ronen et al. (2003) dan Perelberg et al. (2003) melaporkan telah berhasil mengisolasi virus yang identik dengan KHV dari ikan mas dan koi. Hedrick et al. (2005) berhasil mengisolasi KHV dari beberapa organ target antara lain insang, ginjal, limfa, usus, dan hati.

Upaya pemilihan sampel yang tepat sangat penting untuk mendeteksi dan mengidentifikasi penyakit KHV. Hal ini berhubungan dengan pengetahuan organ yang menjadi target serangan $\mathrm{KHV}$, sehingga dapat memudahkan dalam isolasi virus untuk kajian lebih lanjut. Adapun tujuan dari penelitian ini adalah untuk mengetahui jaringan yang menjadi target infeksi KHV dengan cara isolasi virus dari beberapa organ target dengan menggunakan kultur sel KT- 2 .

\section{BAHAN DAN METODE}

\section{Kultur Sel}

Kultur sel yang dipakai dalam penelitian ini adalah kultur sel KT- 2 yang dikembangkan di laboratorium kesehatan ikan (Sunarto et al., 2005b). Kultur sel ditumbuhkan dalam kultur cawan 12 ( 12 multiwell plates) dengan media Leibovitz's L- 15 yang mengandung Fetal Bovine Serum (FBS) 10\% Penicillin 250 IU, Streptomycin $250 \mu \mathrm{g} / \mathrm{mL}$, Kanamycin Sulfat $250 \mu \mathrm{g} / \mathrm{mL}$, dan L- glutamin $2 \mathrm{mM}$. Untuk pasase isolat murni, sel dikultur pada flask kultur dengan luas $25 \mathrm{~cm}^{2}$.

\section{Ikan Sampel}

Ikan uji yang digunakan untuk isolasi virus adalah ikan mas yang secara visual terlihat sakit. Ikan diambil dari Waduk Cirata, Jawa Barat, yang pada waktu tersebut sedang mengalami kasus kematian massal. Gejala klinis ikan sakit adalah berenang di permukaan, lemah, terjadi kerusakan insang dan sirip.

\section{Isolasi Virus}

Ekstrak jaringan (tissue extract) diperoleh berdasarkan Fresney (1994). Organ yang dipakai untuk pembuatan ekstrak jaringan meliputi otak, mata, insang, ginjal, limfa, hati, jantung, usus, dan dari gabungan (pooled) ginjal, limfa, dan insang (3:1:1). Sebanyak $1 \mathrm{~g}$ organ yang dikumpulkan dari 5 ekor ikan diambil secara aseptik, masing-masing dihomogenkan dan diencerkan dengan Hank's balanced salts solution (HBSS) dengan perbandingan 1:10. Suspensi jaringan disentrifus pada kecepatan 1.500 xg selama 15 menit pada suhu $4^{\circ} \mathrm{C}$. Supernatan diencerkan dengan HBSS yang sudah ditambah serum $2 \%$ dengan perbandingan 1:5 dan disaring dengan filter 0,45 $\mu \mathrm{m}$. Sebanyak 0,2 $\mathrm{mL}$ supernatan dari masing-masing ekstrak jaringan diinokulasikan pada kultur sel yang ditanam pada flask kultur 12. Untuk kontrol negatif, kultur sel diinokulasi dengan larutan HBSS dengan volume yang sama. Kultur diinkubasi selama 1 jam, selanjutnya $1,5 \mathrm{~mL}$ media L- 15 ditambahkan ke dalam tiap cawan. 
Kemudian, kultur sel diinkubasi pada suhu $25^{\circ} \mathrm{C}$ selama 14 hari. Parameter yang diamati adalah waktu terjadi CPE (onset) dan jenis kerusakan sel (cytopathic effects, CPE). Pasase buta (blind passage) dilakukan untuk konfirmasi bahwa CPE yang terjadi disebabkan oleh infeksi virus, bukan karena toksisitas inokulum ekstrak jaringan. Pasase tersebut dilakukan sebanyak 3 kali.

\section{Polymerase Chain Reaction (PCR)}

Uji PCR dilakukan dengan menggunakan kits KHV (IQ- 2000, Taiwan) yang menghasilkan produk PCR pada 229 bp dan 440 bp. Tes ini dilakukan untuk memastikan bahwa ikan sampel yang digunakan dalam isolasi adalah terinfeksi KHV. Sampel uji diambil dari gabungan (pooled) insang, ginjal, dan limfa. Tes PCR juga dilakukan untuk konfirmasi terhadap media kultur dan sel yang mengalami kerusakan (CPE) setelah diinokulasi dengan ekstrak jaringan ikan sakit.

\section{HASIL DAN BAHASAN}

Ikan yang dipakai untuk isolasi virus adalah ikan mas sakit yang diambil dari Waduk Cirata yang sedang mengalami kasus kematian massal dengan indikasi terinfeksi KHV. Hal ini ditandai dengan gejala klinis seperti produksi lendir yang berlebihan, insang putih, dan rusak (OATA, 2001). Hasil uji PCR dengan menggunakan kits KHV (IQ- 2000, Taiwan) terhadap ikan mas sampel menunjukkan bahwa ikan sakit disebabkan oleh KHV. Dengan kata lain, kematian massal ikan mas di kolam budidaya tersebut disebabkan oleh KHV (Gambar 1).

Perubahan yang terjadi pada kultur sel yang diinokulasi ekstrak jaringan organ target selama masa pengamatan disajikan pada Tabel 1.

Hasil pengamatan pada kultur sel KT- 2 menunjukkan bahwa pada hari pertama sampai hari kelima setelah dilakukan inokulasi ekstrak jaringan, kondisi sel masih normal (tidak ada perubahan). Perubahan mulai teramati pada hari keenam setelah inokulasi. Khususnya pada kultur yang diinokulasi dengan ekstrak jaringan insang, ginjal, dan gabungan organ (insang, ginjal, dan limfa). Tidak terlihat adanya perubahan pada kultur sel yang diinokulasi dengan ekstrak jaringan dari organ otak, mata, hati, jantung, limfa, dan usus, maupun pada kultur sel yang diinokulasi dengan medium HBSS sebagai kontrol negatif (Gambar 2).

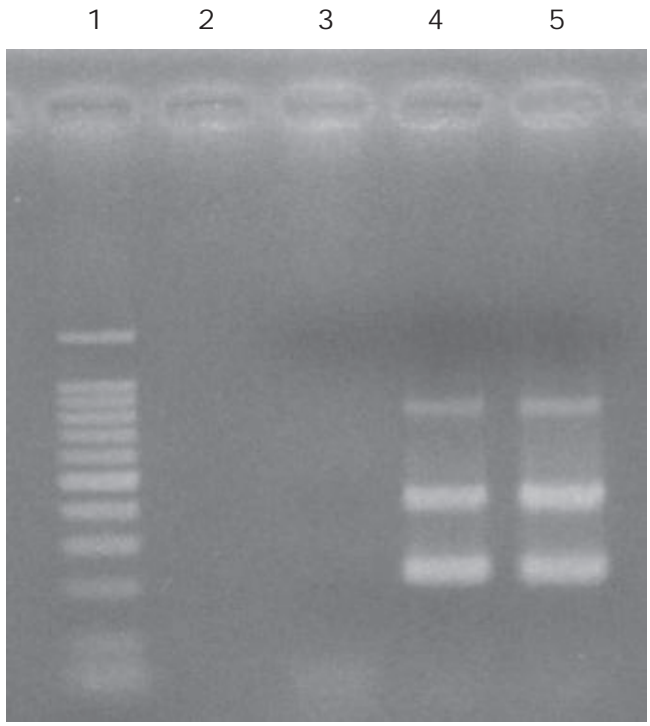

Gambar1. Hasil uji deteksi KHV dengan menggunakan PCR dari ekstrak jaringan ikan mas sakit dan sehat. 1. marker DNA ladder 100 bp; 2. kontrol negatif; 3 . Sampel ikan mas sehat, 4. ikan mas sakit, 5 . kontrol positif

Figure 1. The result of PCR assay for KHV detection of tissue extract from unhealthy and healthy fish. $1.100 \mathrm{bp}$ DNA marker ladder; 2. negative control; 3. Healthy carp; 4. unhealthy carp, 5. positive control

Perubahan yang nyata pada kultur sel (CPE) yang diinokulasi ekstrak insang, ginjal, dan gabungan (insang, ginjal, dan limfa) mulai terlihat pada hari ke- 7. CPE yang teramati antara lain berupa vakuola- vakuola kecil pada kultur sel. Vakuola yang terlihat seperti bintik putih dan berlubang tersebut hanya terdapat di beberapa bagian pada kultur sel. Pada hari ke- 10 , kerusakan sel yang terjadi mulai terlihat lebih nyata yaitu pembentukan vakuola yang lebih besar dan menyebar di sebagian besar kultur sel. Terlihat juga individu sel (single cell) yang terpisah dari sel-sel di sekitarnya. Setelah hari ke- 11 vakuolisasi semakin membesar dan penyebarannya merata pada seluruh permukaan kultur. Vakuolisasi ini diikuti dengan terjadinya pelepasan (detachment) sel dari permukaan cawan kultur (Gambar 3). Pada hari ke - 14 sekitar 95\%dari kultur sel mengalami detachment. 
Tabel 1. Pengamatan pembentukan cytopathic effect (CPE) pada kultur sel KT- 2 Table 1. Observation of the formation of cytopathic effect (CPE) in KT-2 cell culture

\begin{tabular}{|c|c|c|c|c|c|c|c|c|c|c|c|c|c|c|}
\hline \multirow{2}{*}{ Organ } & \multicolumn{14}{|c|}{ Pembent ukan CPE (CPE formation) } \\
\hline & 1 & 2 & 3 & 4 & 5 & 6 & 7 & 8 & 9 & 10 & 11 & 12 & 13 & 14 \\
\hline Insang (Gills) & - & - & - & - & - & + & + & + & ++ & ++ & ++ & +++ & +++ & +++ \\
\hline Ginjal (Kidney) & - & - & - & - & - & + & + & + & ++ & ++ & ++ & +++ & +++ & +++ \\
\hline Otak (Brain) & - & - & - & - & - & - & - & - & - & - & - & - & - & - \\
\hline Mata (Eyes) & - & - & - & - & - & - & - & - & - & - & - & - & - & - \\
\hline Hati (Liver) & - & - & - & - & - & - & - & - & - & - & - & - & - & - \\
\hline Jantung (Heart) & - & - & - & - & - & - & - & - & - & - & - & - & - & - \\
\hline Usus (Intestine) & - & - & - & - & - & - & - & - & - & - & - & - & - & - \\
\hline Limfa (Spleen) & - & - & - & - & - & - & - & - & - & - & - & - & - & - \\
\hline $\begin{array}{l}\text { Gabungan organ*) } \\
\text { (Pooled of organ ) }\end{array}$ & - & - & - & - & - & + & + & + & ++ & ++ & ++ & +++ & +++ & +++ \\
\hline $\begin{array}{l}\text { Kontrol positif } \\
\text { (Positive control) }\end{array}$ & - & - & - & + & + & + & ++ & + & ++ & +++ & +++ & +++ & +++ & +++ \\
\hline $\begin{array}{l}\text { Kontrol negatif } \\
\text { (Negative control) }\end{array}$ & - & - & - & - & - & - & - & - & - & - & - & - & - & - \\
\hline
\end{tabular}

Keterangan (Note):

*) = insang (gills), ginjal (kidney), limfa (spleen)
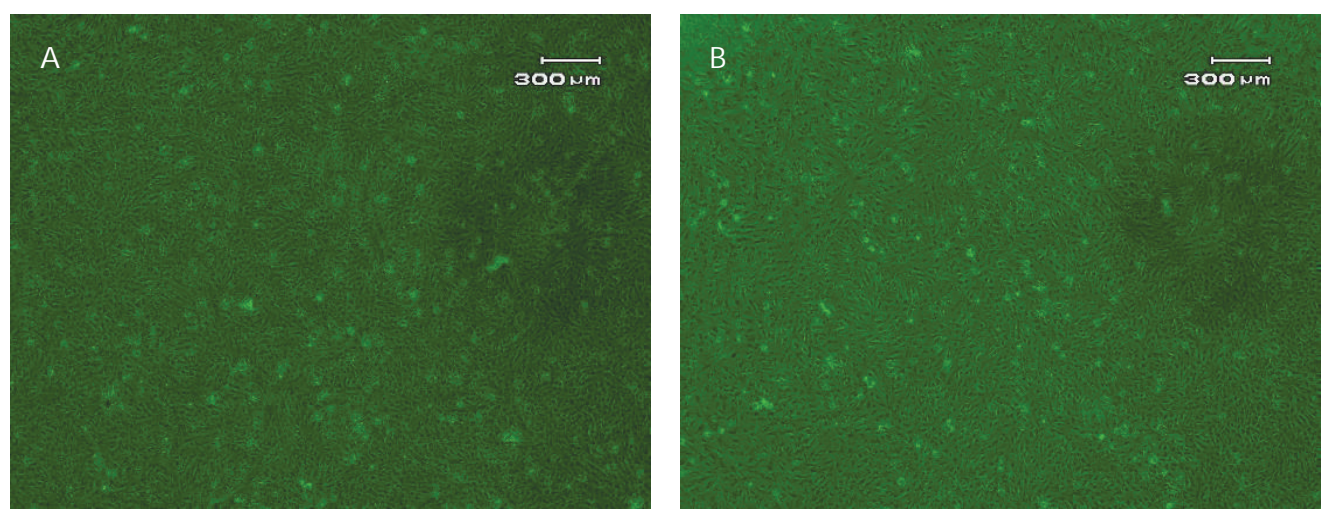

Gambar 2. Isolasi KHV menggunakan kultur sel KT- 2. (A) Kultur sel KT- 2 yang diinokulasi dengan medium HBSS (kontrol negatif). (B) Kultur sel KT- 2 yang diinokluasi ekstrak jaringan organ target tetapi tidak menunjukkan CPE

Figure 2. Isolation of KHV using KT-2 cell culture. (A) KT-2 cell cultures inoculated with HBSS medium (negative control). (B) KT-2 cell cultures inoculated with tissue extracts from target tissue but did not showed CPE

Pada akhir pengamatan selama 14 hari, tidak terlihat adanya kerusakan sel yang menunjukkan CPE pada kultur yang diinokulasi dengan ekstrak jaringan dari otak, mata, limfa, hati, jantung, dan usus (Tabel 2).
Hasil pengamatan pada kultur sel yang diinokulasi dengan isolat KHV (kontrol positif) yang diikuti dari hasil pasasenya menunjukkan CPE. CPE teramati pada hari ke- 4 setelah inokulasi, 3 hari lebih cepat dari CPE yang 

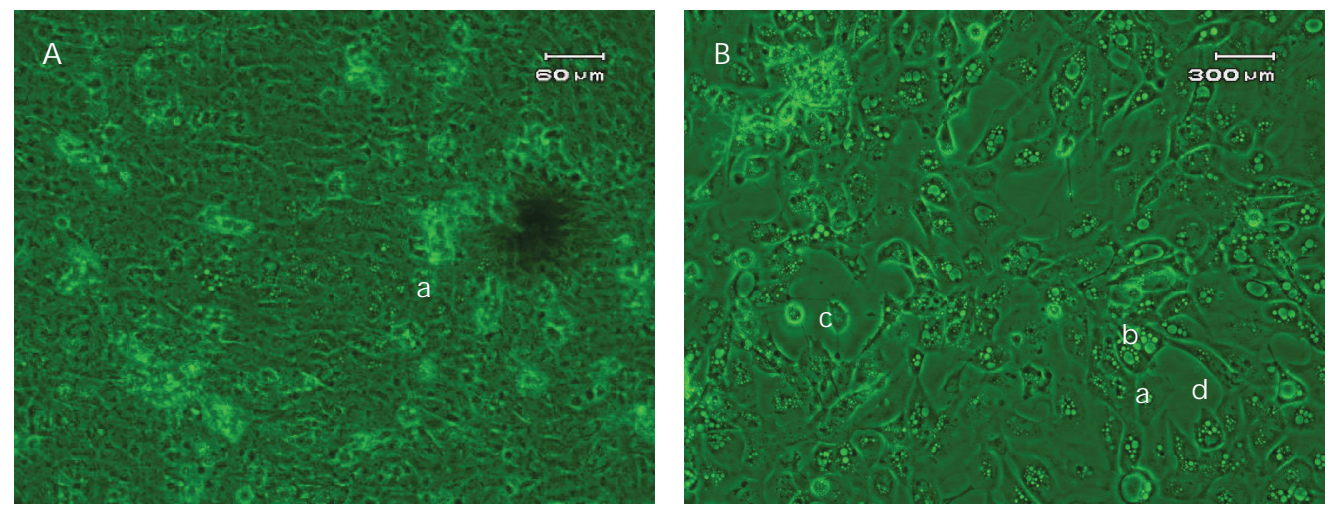

Gambar 3. Kultur sel KT- 2 yang diinokulasi dengan ekstrak jaringan insang, ginjal, dan gabungan organ (insang, ginjal, dan limfa) menunjukkan CPE pada hari ke- 7 (A) dan hari ke- 10 (B) setelah inokulasi. a. Vakuola kecil, b. Vakuola besar, c. Pembentukan individu sel, dan d. Permukaan cawan yang kosong karena sel sudah terlepas (detached) dari dasar cawan

Figure 3. KT-2 cell cultures inoculated with tissue extracts from gill, kidney, and pooled of organs (gills, kidney, and spleen) showed CPE on 7 (A) and 10 (B) post inoculation. a. small vacuoles, $b$. large vacuoles, $c$. development of a single cell, and $d$. empty space due to the cells have detached from the flask

Tabel 2. Hasil isolasi virus dari beberapa organ target pada ikan mas

Table 2. The isolated virus from several target organs in common carp

\begin{tabular}{lc}
\hline \multicolumn{1}{c}{$\begin{array}{c}\text { Organ target } \\
\text { Target organ }\end{array}$} & $\begin{array}{c}\text { Kerusakan sel } \\
\text { Cytophathic effect/CPE }\end{array}$ \\
\hline Otak (Brain) & - \\
Mata (Eyes) & - \\
Insang (Gills) & + \\
Ginjal (Kidney) & + \\
Limfa (Spleen) & - \\
Hati (Liver) & - \\
Jantung (Heart) & - \\
Usus (Intestine) & - \\
Gabungan insang, ginjal, dan limfa & + \\
Pooled of gills, kidney, and spleen & \\
Kontrol negatif (Negative control, HBSS) & - \\
Kontrol positif (Positive control) & + \\
\hline
\end{tabular}

terjadi pada saat isolasi virus (kultur sel yang diinokulasi dengan ekstrak jaringan insang, ginjal, dan gabungan (insang, ginjal, dan limfa) ikan mas sakit. CPE tersebut ditandai dengan adanya vakuola kecil di beberapa tempat, kemudian berkembang secara ekstensif. Pelepasan sel terjadi mulai hari ke- 7. Hasil yang sama dijumpai pada pasase yang dilakukan berulang dari pasase ke- 1 sampai pasase ke3. Hasil PCR dengan menggunakan kits KHV (IQ- 2000) pada media kultur dan sel yang menunjukkan CPE memperlihatkan hasil positif. Hal ini menunjukkan bahwa kultur sel benarbenar terinfeksi KHV (Tabel 3). 
Tabel 3. Hasil uji PCR pada media kultur dan sel dari kultur sel yang menunjukkan CPE

Table 3. The results of PCR assays on the cell culture medium and cells from cell cultures showing CPE

\begin{tabular}{|c|c|c|}
\hline \multirow[b]{2}{*}{ Pasase KHV (Passage of KHV) } & \multicolumn{2}{|r|}{ Uji PCR (PCR assays) } \\
\hline & $\begin{array}{l}\text { Sel } \\
\text { Cell }\end{array}$ & $\begin{array}{c}\text { Media kultur sel } \\
\text { cell culture medium }\end{array}$ \\
\hline $\begin{array}{l}\text { Inokulasi dengan ekstrak jaringan ginjal, } \\
\text { insang dan gabungan organ*) }\end{array}$ & + & + \\
\hline \multicolumn{3}{|l|}{$\begin{array}{l}\text { Inoculated with tissue extracts from gills, } \\
\text { kidney, and pooled of organ*) }\end{array}$} \\
\hline Pasase ke-1 (Passage 1 ) & + & + \\
\hline Pasase ke-2 (Passage 2) & + & + \\
\hline Pasase ke-3 (Passage 3) & + & + \\
\hline
\end{tabular}

Isolasi KHV pertama kali dilakukan dari kasus kematian massal pada budidaya ikan mas di Israel dan Amerika dengan menggunakan kultur sel KF- 1 (Hedrick et al., 2000). Meskipun penyebarannya sangat cepat, penyakit ini dilaporkan hanya menyerang pada ikan mas dan koi (Perelberg et al., 2003). Di Indonesia, KHV pertama kali berhasil diisolasi dari gabungan insang, ginjal, dan limfa dari ikan koi yang berasal dari kolam yang sedang mengalami kasus kematian massal di Jawa Barat dengan menggunakan kultur sel KT- 2 (Sunarto et al., 2005b, Sumiati \& Sunarto, 2009). CPE teramati pada hari ke- 6 setelah inokulasi. Demikian halnya dengan penelitian ini, CPE mulai teramati pada hari ke- 6 setelah inokulasi pada kultur sel yang diinokulasi dengan ekstrak jaringan dari insang, ginjal, dan gabungan (insang, ginjal, dan limfa). Usaha isolasi virus dari otak, mata, limfa, hati, jantung, dan usus belum berhasil menunjukkan CPE, namun hal ini tidak berarti bahwa organ- organ tersebut bukan merupakan target organ infeksi KHV. Berdasarkan uji PCR yang pernah dilakukan, selain insang, ginjal, dan limfa, KHV juga terdeteksi hampir dari semua organ ikan (Hedrick et al., 2000; Gray et al., 2002; Gilad et al., 2003; Gilad et al., 2004). Meskipun Hedrick et al. (2005) melaporkan telah berhasil mengisolasi KHV dari berbagai organ antara lain insang, ginjal, limfa, usus, dan hati, tapi dinyatakan juga bahwa isolasi virus dengan menggunakan kultur sel sangat sulit dilakukan. Kesulitan dalam isolasi virus KHV juga dilaporkan oleh beberapa negara termasuk Jepang (Sano et al., 2004), Taiwan (Tu et al., 2004), Thailand (Pikulkaew et al., 2009), dan Filipina (Somga et al., 2010). Hal ini diduga karena virion KHV sangat labil, sehingga sampel untuk keperluan isolasi virus perlu penanganan khusus. Gilad et al. (2004) melaporkan bahwa sampel untuk isolasi KHV harus diproses dalam hitungan jam setelah ikan mati dan cukup sulit untuk melakukan isolasi KHV dari sampel yang telah disimpan beku. Sunarto et al. (2011) melaporkan bahwa kesulitan isolasi KHV dapat disebabkan oleh beberapa hal antara lain: (1) terbatasnya kultur sel yang cocok untuk isolasi KHV, (2) kesulitan memelihara kultur sel yang ada, (3) kultur sel yang ada kurang sensitif untuk isolasi KHV, (4) titer yang tinggi pada saat infeksi KHV sangat singkat.

Berdasar hasil riset ini, untuk keperluan diagnosa dan isolasi virus hidup, sebaiknya digunakan organ insang atau ginjal seperti dinyatakan juga oleh Hedrick et al. (2000), Gray et al. (2002), dan Gilad et al. (2003). Keberhasilan isolasi virus dari jaringan organ insang, ginjal dan gabungan organ (insang, ginjal, dan limfa) mungkin disebabkan konsentrasi virus di insang, ginjal, dan limfa sangat tinggi yaitu $10^{8}-10^{9}$ virus per $10^{6} \mathrm{sel}$ ikan (Gilad et al., 2004). 
Sampai saat ini belum ada obat yang efektif untuk penyakit KHV. Oleh karena itu, penanggulangan penyakit KHV lebih difokuskan pada strategi pencegahan. Upaya penanggulangan harus berbasis ramah lingkungan. Upaya pencegahan dengan metode vaksinasi menjadi solusi alternatif yang bisa dilakukan. Keberhasilan dalam isolasi KHV di Indonesia dengan menggunakan kultur sel diharapkan dapat dijadikan acuan dalam program vaksinasi untuk penanggulangan penyakit KHV.

\section{KESIMPULAN DAN SARAN}

Koi herpesvirus berhasil diisolasi dari jaringan organ insang, ginjal, dan gabungan organ (insang, ginjal, dan limfa) ikan mas dari Waduk Cirata. Hasil uji PCR dari media kultur sel dan sel yang memperlihatkan CPE menunjukkan bahwa CPE disebabkan oleh KHV.

Untuk keperluan isolasi virus KHV disarankan menggunakan sampel dari organ insang, ginjal atau gabungan insang, ginjal dan limfa. Diagnosa penyakit KHV dengan menggunakan metode lain seperti PCR, hibridisasi in situ dan ELISA disarankan menggunakan sampel dari ginjal dan insang.

\section{DAFTAR ACUAN}

Freshney, R.I. 1994. Culture of animal cells: A manual of basic technique. $3^{\text {rd }}$ ed. WileyLiss. Inc. USA, 486 pp.

Gilad, O., Yun, S., Andree, K.B., Adkison, M.A., Way, K., Willits, N.H., Bercovier, H., \& Hedrick, R.P. 2003. Molecular comparison of isolates of an emerging fish pathogen, the koi herpesvirus, and the effect of water temperature on mortality of experimentally infected koi. J. Gen. Virol., 84: 2,661- 2,668.

Gilad, O., Yun, S., Zagmutt-Vergara, F., Leutenegger, C.M., Bercovier, H., \& Hedrick, R.P. 2004. Concentrations of a herpes- like virus (KHV) in tissues of experimentally-infected Cyprinus carpio koi as assessed by real- time TaqMan PCR. Dis. Aquat. Org., 60: 179- 187.

Gray, W.L., Mullis, L., LaPatra, S.E., Groff, J.M., \& Goodwin, A. 2002. Detection of koi herpesvirus DNA in tissues of infected fish. $J$. Fish. Dis., 25: 171- 178.

Hedrick, R.P., Gilad, O., Yun, S., Spangenberg, J.V., Marty, G.D., Nordhausen, R.W., Kebus M.J., Bercovier, H., \&Eldar, A. 2000. A herp- esvirus associated with mass mortality of juvenile and adult koi, a strain of a common carp. J. Aquat. Anim. Health., 12: 44- 57.

Hedrick, R.P., Gilad, O., Yun, S.C., Mcdowell, T.S., Waltzek, T.B., Kelley, G.O., \&Adkison, M.A. 2005. Initial isolation and characterization of a herpes- like virus (KHV) from koi and common carp. Bull. Fish. Res. Agen. Supplement, 2: 1- 7.

Hoffman, R.W., Just, J., \&El- Matbouli, M. 2002. Koi herpesvirus infection in koi and common carp in Germany. Abstract of 10 International Conference of the European Association of Fish Pathologist, Dublin, Germany, $131 \mathrm{pp}$.

Neukrich, M. \& Kunz. 2001. Isolation and preliminary characterization of several viruses from koi (Cyprinus carpio) suffering gill necrosis and mortality. Bull. Eur. Ass. Fish Pathol., 21(4): 125- 135.

Ornamental Aquatic Trade Association (OATA). 2001. Koi Herpes Virus (KHV). OATA, Wetsbury, Wilts, UK, p. 4- 33.

Perelberg, A., Smirnov, M., Hutoran, M., Diamant, A., Bejerano, I., \& Kotler, M. 2003. Epidemiological description of a new viral disease afflicting cultured Cyprinus carpio in Israel. Isr. J. Aquacult. Bamidgeh, 55: 512.

Pikulkaew, S., Meeyam, T., \&Banlunara, W. 2009. The outbreak of koi herpesvirus (KHV) koi (Cyprinus carpio koi) from Chiang Mai Province, Thailand. Thai Journal of Veterinary Medicine, 39: 53-58.

Ronen, A., Perelberg, A., Abramowitz, L., Hutoran, M., Tinman, S., Bejerano, I., Stevitz, M., \& Kotler, M. 2003. Efficient vaccine against the virus causing a lethal disease in culture Cyprinus carpio. Vaccine, 21: 4,6774,684.

Sano, M., Ito, T., Kurita, J., Yuasa, K., Miwa, S., \& lida, T. 2004. Experience on common carp mass mortality in Japan. 2004. in "Transboundary fish Disease in Southeast Asia: Occurrence, Surveillance, Research and Training" (Eds.) C.R. Lavilla- pitogo, C.R. \& Nagasawa, K. SEAFDEC Aquaculture Department, llo- Ilo, Philippines, p. 13- 21.

Somga, J.R., de la Pena, I.D., Sombito, C.D., Paner, M.G., Suarnaba, V.S., Capulos, G.C., Maria, P.I., \& Lio- Po, G. 2010. Koi herpesvirusassociated mortalities in quarantined koi carp in the Philipines. Bulletin of the European Association of Fish Pathologists, 30: 2-7. 
Sumiati, T. \& Sunarto, A. 2009. Susceptibility of Cyprinid and Non-Cyprinid Fish Cell Lines to Koi herpesvirus (KHV). Indonesian Aquaculture Journal, 4(2): 131-137.

Sunarto, A. \& Cameron, A. 2005. Response to mass mortality of carp: an Indonesian experiences. In Subasinghe, R.P. \&Arthur, J.R. (Eds.) Regional Workshop on Preparedness and Response to Aquatic Animal Health Emergencies in Asia. FAO Fisheries Proceedings. No. 4. Rome, p. 87- 106.

Sunarto, A., Taukhid, Rukyani, A., Koesharyani, I., Supriyadi, H., Huminto, H., Agungpriyono, D.R., Pasaribu, F.H., Widodo, Herdikiawan, D., Rukmono, D., \& Prayitno, S.B. 2005 a. Field investigation on serious disease outbreak among koi and common carp (Cyprinus carpio) in Indonesia. In Walker, P.J., R.G. Lester and M.G. Bondad Reantaso (eds). Diseases in Asian Aquaculture V. Fish Health Section, Asian Fisheries Society, Manila, p. 125- 136.

Sunarto, A., Sumiati, T., Koesharyani, I., Hyatt, A., \& Itami, T. 2005b. Development of cell line from tail of koi (Cyprinus carpio) and isolation of koi herpesvirus from Indone- sia aquaculture. Book of abstracts $6^{\text {th }}$ Symposium on Diseases in Asian Aquaculture, 25- 28 October 2005. Colombo. Srilanka, 74 $\mathrm{pp}$.

Sunarto, A., McColl, K.A., Crane, M.St., Sumiati, T., Hyatt, A.D., Barnes, A.C., \& Walker, P.J. 2011. Isolation and characterization of koi herpesvirus (KHV) in Indonesia: identification of a new genetic lineage. Journal of Fish Diseases, 34: 87-101.

Tu, C., Lin, S.Y., \& Sung, H.T. 2004. Current status of Koi herpesvirus disease in Taiwan. 2004. in "Transboundary fish Disease in Southeast Asia: Occurrence, Surveillance, Research and Training" (Eds.) Lavilla- pitogo, C.R. \& Nagasawa, K. SEAFDEC Aquaculture Department, Ilo- Ilo, Philippines, p. 21- 24.

Way, K., Le Deuff, R.M., Ecclestone, L., Feist, S.W., Dixon, P.F., Wildgoose, W.H., \& Hedrick, R.P. 2002. Isolation of a herpesvirus during disease outbreaks in adults koi carp, Cyprinus carpio, in the UK. Abstract of 10 International Conference of the European Association of Fish Pathologist, Dublin, Germany, 129 pp. 